Fracture of Skull, Rupture of Meningeal Artery. Ligation of Common Carotid, Recovery.

A thexs, IrL., July 10, 1897.

To the Elitor:-Believing the following case would be of interest to the readers of the JouknaL, I will report it as briefly as possible:

On Wednesday, April 15, 1897, I was called to see T. J. S., carpenter by occupation, age 28, American, and found him lying on the bed profoundly unconscious, pulse 40, breathing stertorous, right pupil dilated, and obtained the following history: Some four hours previously while engaged in building a barn a piece of timber, oak $2 \times 8$ inches, 11 feet in length, fell from upper part of barn frame while being placed in position by an assistant and dropped a distance of eight or ten feet, striking $\mathrm{S}$. on the top of the head, felling him to the ground, but did not produce immediate unconsciousness. At time of accident he wore a very thick cap on his head, which probably explained absence of external evidence of injury, as close exam ination of head failed to reveal anything more than a small dis colored spot at the point of injury. After receiving the injury he mounted his horse and rode to his home distant about two miles and gave his wife an intelligent account of the accident and requested that the family physician be called. Unconsciousness developed slowly and at expiration of four hours after injury had become profound. I diagnosed fracture of skull with compression of brain and asked for surgical consultation.

Dr. J. A. Prince of Springfield, Ill., saw the case with me and concurred in the opinion expressed, and operation was decided upon, which was performed a few hours later, the patient not showing the slightest evidence of improvement in any way, having lost control of sphincter muscles and having involuntary passages from bowels and bladder.

Incision was made through soft tissues of the scalp down to the skull at the point of injury, and fracture of right parietal bone near superior border was found extending downward and forward considerable distance but no depression of bone. On removal of section of bone with trephine a very firm blood clot presented in the opening, which was enlarged with bone cutting forceps, and clot removed, after which hemorrhage from the middle meningeal artery was very profuse. Packing the opening with gauze, firm pressure and compression failed to control the bleeding. To accomplish this purpose we decided, after giving other methods a fair trial to ligate the right common carotid artery, which was performed in the usual way, the vessel being tied with a double silk ligature, the result was all that could be desired and the operation was concluded in the usual manner and patient put to bed. In a few hours consciousness returned, the pupillary inequality disappeared and the patient made an uneventful recovery, and at this time, now almost three months after operation, expresses himself as being as well in every way as he ever was in his life; he is going about as usual and expects to resume work at his trade at once.

A. L. Brittin, M.D.

\section{An Open Letter.}

Iowa City, Iowa, July 5, 1897.

To the Medical Profession, Members of the Legislature and Citizens of Iowa:

You are doubtless aware that the Board of Regents of the University of the State of Iowa have appropriated nearly $\$ 150,000$ for the construction and equipment of an hospital to be an adjunct to the Medical Department of the University.

This hospital has been planned to possess the greatest amount of facility for medical and surgical work possible in the present state of science; and, under proper restrictions, it might become a source of great benefit to the needy and indigent requiring medical or surgical treatment.
But the best information accessible indicates that the use and control of the hospital is to be restricted to members of the Faculty of the Medical Department of the State University, and that the practical working of the hospital is to be largely under the control of non-resident members of the faculty.

We are also informed that while it is the intention of those in authority to admit the poor, if funds for their board be guaranteed by friends, or by the county from which they come, the well to-do are to be received and afforded advantages superior to those that can be given by local physicians and surgeons, or by local hospitals or sanitariums, provided they pay their board and reasonable charges to the physician or surgeon in charge.

Thus the State, in behalf of a few individuals connected with the Faculty of the Medical Department of the University, enters into competition with every general practitioner, and every hospital and sanitarium in the State; also offering to furnish a set of operating rooms, and all special appliances, to the members of the staff without expense to them; thereby giving them great advantages in competition with the large body of the medical profession, who have no such extraneous aid.

We call your attention to this matter in the hope that you may aid in obtaining from the legislature such enactments as will secure the enforcement of the following rules; without which, in our belief, the hospital should receive no help from the State or the medical profession :

1. That no patient shall be admitted to the hospital or receive treatment therein who is able to pay, or possesses sufficient means to pay for his or her treatment at home, or in a private institution.

2. That no physician or surgeon, a member of such hospital staff, shall receive any compensation for service in such hospital, or receive any pay or gratuity from any patient admitted to such hospital.

It is our belief that the adoption of such rules would in no way lessen the opportunity for good of a State hospital, and could in no way interfere with the legitimate work of the members of its staff. Respectfully submitted,

Elmer F. Clapp, M.D., Iowa City, Iowa.

C. M. Новву, M.D., Iowa City, Iowa.

A Query.

Fort Yates, N. Dak., July 7, 1897.

To the Editor:-Would you kindly give the formula and method of using Schleich's fluid for anesthesia, and as full particulars as possible of Maragliano's serum, in your next issue? Yours very faithfully,

J AMES W. Baird, M.D.

Answer: See The Journal, Dec. 29, 1894, p. 965, for Dr. Würdemann's article on Schleich's method, and ThF JournaL, Nov. 21, 1896, p. 1105, for an abstract of an article on Maragliano's serum.

\section{BOOK NOTICES.}

Manuali Hoepli. Soccorsi d'Urgenza. Pel Dottore Carlo CalliANo. Milano: Ulrico Hoepli. 1897. (Aid in Emergencies.) 4 ta edizione.

La Morte Vera e la Morte Apparente. Con Appendice “ La Legislatura Mortuaria." Pel DotTore Felice Dele'Acqua. (Real and Apparent Death, with Appendix, Mortuary Legislation.) Milano: Ulrico Hoepli. 1897.

The first of these two little volumes of the extensive and comprehensive Hoepli series, is a work that has received the approval of the Italian sanitary authorities and has passed through four editions, which facts ought to be an index to its worth. On examination the favorable presumption is con- 